\title{
Water, Population Growth and Contagious Diseases ${ }^{\dagger}$
}

\author{
Maurizio Iaccarino \\ Institute of Genetics and Biophysics “A. Buzzati-Traverso", CNR, 111 Via Pietro Castellino, 80131 Naples, Italy; \\ iaccarin@igb.cnr.it; Tel.: +39-0816132431 \\ † This paper is an elaboration of the text of a lecture given at the International Congress “Laudato si'y Grandes \\ Ciudades", which took place in Rio de Janeiro, Brazil, in July 2017.
}

Received: 19 December 2018; Accepted: 19 February 2019; Published: 22 February 2019

\begin{abstract}
Water, essential for the biology of living organisms, is also important for agriculture, for the organization of social life and for culture. In this review we discuss the interrelationship between water availability and human population size. The total population of the globe, 3-5 million people between the years 25,000 and 5000 Before Common Era (BCE), increased about 50-fold in coincidence with the development of agriculture. Later on, after the year 200 Common Era (CE), the number of people did not change appreciably and increased slowly in the period 1000 to $1500 \mathrm{CE}$. We show that the main cause of this observed slow-down in population growth was the increase in population density, which caused the appearance and spreading of infectious diseases, often due to the use of contaminated water. Population started to increase again when people learned how to use appropriate sanitation and hygienic rules. The management of water resources, including transport of water to the areas where it is needed, separation and depuration of wastewater and production of freshwater by desalination, have become increasingly important. The population level is today very high and will continue to grow, thus causing a further increase in the density of people and an increased risk of contagious diseases. Therefore, more water for sanitation will be needed all over the world.
\end{abstract}

Keywords: freshwater needs; population density; epidemics; sanitation; global water requirements

\section{Introduction}

Water covers $70 \%$ of the surface of planet Earth. It is a thin layer, representing only $0.2 \%$ of the mass of our planet and it is found in a liquid or solid state or as a vapor. Most of the water (96.5\%) is in the oceans, $1.7 \%$ is in the glaciers, $0.015 \%$ is in rivers, lakes and soil moisture; $1.6 \%$ is located underground, mainly in the aquifers. Humans use freshwater, namely water containing less than 0.5 parts per thousand of dissolved salts. It is estimated that the water volume of rivers is $2100 \mathrm{~km}^{3}$ and that lakes and aquifers contain $91,000 \mathrm{~km}^{3}$ and $10,530,000 \mathrm{~km}^{3}$ of water, respectively. Water is used mainly (70-75\%) for irrigation; $10-12 \%$ of it is used for direct human purposes (sanitation and drinking) and 15\% for industrial uses (cooling, cleaning, processing, generating steam power) [1-3].

Freshwater comes from the water that precipitates on the ground: part of it replenishes rivers and lakes, part of it infiltrates the ground and stops where it finds an impermeable layer (for example clay), thus forming the aquifers [4]. The aquifers provide almost $20 \%$ of the freshwater used by humans but are not useful when, in $55 \%$ of the cases, they contain too much salt. In some cases, aquifers are contaminated with harmful chemical compounds; this may be a serious problem since it is almost impossible to decontaminate an aquifer, which as a consequence must be abandoned or the water extracted should be purified. The amount of water present in aquifers can vary with the seasons and sometimes a massive extraction leads to their exhaustion. Aquifers can cross one or more States and hence sometimes the use of water by a State can impoverish the portion of the aquifer that is beyond its 
boundary; in this case their management requires international collaboration and intergovernmental agreements. Indeed, in 2009 the UN approved a resolution that regulates relations between States for their use. The signatories of this resolution committed themselves to: (1) make a fair and reasonable use of cross-border aquifers located in their territory and, in cooperation with the other States involved, prepare a long-term plan of use; (2) avoid polluting the aquifers in their territory to prevent damage to neighbouring States. An inventory, compiled in 2015 by the International Groundwater Resources Assessment Centre, contains a list of 592 cross-border aquifers.

Water moves continuously from the oceans to rivers and back to the oceans. In 1715 Halley proposed the hydrological cycle: water evaporates from the seas and from the surface of the emerged lands and it then precipitates in the form of rain on the Earth's surface (including both the mainland and the oceans); the rain that falls on Earth flows on the ground and then, through the rivers, it reaches the sea [5]. The salinity of the oceans comes in part from erosion and transport from the mainland of salts dissolved in the water of the rivers but salts may also come from minerals dissolved from the bottom of the oceans.

Human beings need to drink 2 litres per day and have an autonomy of only 5 days. Water is essential for the life of cells because it is a solvent for macromolecules and participates in many biochemical reactions. The cell membrane is impermeable to water but special proteins forming the aquaporin channels [6] permit the transport of water, thus allowing the regulation of its intracellular concentration in specific cells [7]. This suggests that water may have different functions in different cells of the body and that the requirement for drinking water might be of crucial importance only for specific cells. Water is an important component of the fluids that surround the cells: it facilitates the movements of joints; it is essential for the uptake and digestion of nutrients, for their transport to all parts of the body and for the excretion of waste through urines. In human beings it is needed for the regulation of body temperature by means of sweating. The human body contains between $45 \%$ and $65 \%$ of water; this value decreases rapidly after death.

The salt concentration in the body of multicellular organisms, including plants, cannot increase over certain levels. Therefore, although living species presumably originated in the oceans, today they cannot withstand their high saline concentration (an average of $35 \mathrm{~g} \mathrm{NaCl}$ per liter, as compared to $9 \mathrm{~g}$ per litre in the blood of human beings). Perhaps, when living beings evolved the salt concentration of the seas was lower than that observed today [8,9].

Salt toxicity might be due to an inhibition of water uptake through the membrane of some cells. In a certain sense it is analogous to the "reverse osmosis" effect: when salt is added to one side of a porous membrane it will cause water to move to the side where salt is added in order to dilute it and to achieve an equal salt concentration on either side of the membrane. Recently, evidence has been reported for osmotic homeostasis mediated by ion transport proteins and aquaporins in the gill of a fish (genus Cyprinodon) after freshwater and seawater acclimation [10]. Recent studies address the problem of salinity stress tolerance in plants in view of difficulties that may arise consequent to climate change and/or lack of water for irrigation [11].

In this review we discuss the relationship between water availability and the expansion of humans on Earth.

\section{Water Availability and Human Population Growth}

The necessity to find freshwater has been of utmost importance for humanity and has influenced the individual way of life and the organization of society. The earliest human settlements have been found predominantly near the borders of rivers or lakes. Parts of skeletons and remains of hunting tools were found in Ethiopia at the banks of some rivers; their dating indicates that they are 2-3 million years old and are the oldest among those today known. The rivers were used for drinking and refreshing; moreover, they were also places where food could be obtained through fishing and hunting. According to Herodotus, the fish were dried in the sun, grinded in a mortar, reduced to flour and then 
used to make buns or pies [12]. Hunting was facilitated by the fact that the rivers were also used for drinking by animals and hence the hunters would find it easier to catch them.

Our remote ancestors were hunter-gatherers, namely they obtained most of their food by killing wild animals or by collecting the fruits of wild plants. They lived near rivers or lakes to use water and moved to better places when the local resources became insufficient. The global population size did not increase appreciably, perhaps because of the high mortality rate but also because for nomadic groups it is difficult to take care of babies. A drastic increase in population growth was only possible following the change in the human lifestyle associated with the appearance of practices for food production. Agriculture started about 11,000 years ago, although in some parts of the world an increase in population size, probably correlated to an increased food production, started already 20,000 years ago [13].

Most anthropologists believe that agriculture was developed independently in different parts of the planet and after some time its progress became more rapid because knowledge and tools were brought to other places where the development of agricultural practices was already starting $[14,15]$. Three elements were crucial and they mutually reinforced each other: (1) plant domestication (namely the selection of plants suitable for human use); (2) animal domestication (namely the use of animals, like cattle and sheep, which helped working in the fields but also were useful for the production of milk and meat); and (3) abundant irrigation (which is essential to increase the fertility of the soil). Progress in these fields was probably not achieved through study and planning but by chance observation of the advantages obtained.

Plant domestication started with the use of specific plants that were found to be useful from a nutritional point of view. Later on people learned how to propagate them for the following year and in this way increased their production. Archaeologists find that the equivalent of modern ceramics was associated with the use of plants and this suggests that our ancestors discovered that cooking helped eating and digestion of plant products. Ceramic artefacts appear with the Neolithic, probably because in the Palaeolithic all food available was immediately consumed [16]. Studies with modern techniques show that plants typical of a certain region were brought and used somewhere else, even at a long distance, thus suggesting that their use was appreciated. Of course, due to climatic reasons, it was more efficient to move specific plants in an East-West-East direction than in a North-South-North direction, as indicated by the analysis of plant distribution and its comparison to their site of origin. It is likely that in many parts of the world the development of agriculture was slower because of the lack of useful plant species. With time, preference was given to plants that for empirical reasons were found to be more useful. Today we see that only a dozen plant species account for more than $80 \%$ of the annual crop on the Earth: five grains (wheat, corn, rice, barley and sorghum), one legume (soy), three tubers (potatoes, manioc and sweet potatoes), two sugar plants (sugar cane and sugar beet) and a fruit plant (banana). Cereals provide more than half of the calories consumed by the world's population [15]. Most people are fed with food produced in a farm and, if the current trend continues, within a short time the latest groups of hunter-gatherers will convert to agriculture, thus ending millions of years of history.

Animal domestication has been an important factor in the promotion of population growth because it was useful to increase agricultural productivity. Domestication implies to use animals that accept to live with human beings. Not all animal species can be domesticated: it appears that it is possible with animals that live in a herd and recognize a dominant member and a fixed hierarchy for each member of the herd. Apparently, they accept domestication when they recognize a human being as the leader of the herd and transmit this behaviour to the pets that are born in captivity [14]. Domestic animals provide meat, milk, wool and leather; their manure is very useful as a field fertilizer and sometimes it is used, after desiccation, to be burned to produce heat. They are also a source of energy, because they pull the ploughs and help moving agricultural machinery; thus, animals make it possible to overturn soils that would otherwise be left untreated and therefore contribute to increase the efficiency of farming. For a long time, they have been the only land transport available. Of course, 
they need food and therefore consume part of the energy they provide; an analysis of the energy produced and consumed by domestic animals has been discussed [17]. Meat from domestic animals replaced game as the primary source of protein and therefore the importance of hunting decreased.

Irrigation promotes an increase in agricultural productivity; on the other hand, the amount of water needed increases when the soil becomes potentially more productive as a consequence of plant and animal domestication. Thus, it was more efficient to use the new agricultural techniques in those parts of the planet where water was abundant and available constantly during the months of the ripening season of the plants. Agriculture started independently in different parts of the world: one of them was Mesopotamia, mainly because of the frequent flooding of the Tiger and Euphrates rivers and from there it expanded to the nearby zone, called the Fertile Crescent. It then reached Egypt, which was blessed by the river Nile. The floods of this river cover the two river banks with abundant water containing a nutrient-rich silt. They arrive once per year (due to the equatorial rains that fall upstream) and their arrival can be predicted with precision. The Egyptians built canals and reservoirs to improve the use of water, which was then assigned to specific farms. The farmers became sedentary and built huts (on the ground or on palisades) and stables for animals. They soon realized the importance of water availability for agricultural production and for this reason they developed structures to improve irrigation opportunities. This social system needed the collective work of many people and thus led to the necessity of a central authority, which was easily accepted. If a farm is used only for the cultivation of plants used for human nutrition one hectare of land can support the life of many more people (10 to 100 times) as compared to a piece of virgin land used by hunter-gatherers. On the other hand, sedentarism is associated with a decrease in mortality of infants as well as of adults, thus causing an increase in population size. As a consequence, more food is needed, thus favouring the groups that improve agricultural productivity. But of course more water per hectare is needed to support a higher level of productivity.

It should be noted that farmers live in a small portion of their cultivated land and prefer to live on the side of their property which is close to places inhabited by other farmers; therefore, when they were not working, their actual density was higher than that calculated per $\mathrm{km}^{2}$ of their farm and they often found it useful to build structures for collective use. This societal structure is an opportunity for the development of cultural relationships and for information exchanges.

Agriculture caused an increase in population size (see below) and induced new forms of social interactions. At the same time, as described in the following chapter, this facilitated different types of contaminations, as for example human contacts with excrements of animal or human origin that cause transmission of pathogens through complex pathways. In the absence of sanitation and sewerage facilities that isolate faecal material from the environment, pathogenic microorganisms can spread into fields and ambient waters and thus cause the appearance of many epidemics [18]. Contamination with faecal sources has been shown to be harmful in recreational water bodies [19] or in child nutrition [20].

\section{Contagious Diseases Limit the Rate of Population Growth}

The size of the total population of the planet in pre-modern times is difficult to determine; the estimates reported by experts are extrapolations from archaeological findings and only few of them quote confidence intervals. In the absence of a straightforward means to assess the error of such estimates, a rough idea of expert consensus can be gained by comparing values given in independent publications. More recently the statistical analysis of sequence variations of genomes of contemporary humans has given information on the number of individuals present in the past $[21,22]$ but these data are restricted to specific geographic areas.

Data reported by different authors [23,24] and quoted by Kremer [25] indicate that in the years 25,000 to $5000 \mathrm{BCE}$ the total population of the planet was rather constant, at a level of 3 to 5 million people; it then started to increase (50 million people in the year $1000 \mathrm{BCE} ; 190$ million people in the year $200 \mathrm{CE}$ ). However, in the following years the global number of people increased only slightly, to 265 million in the year $1000 \mathrm{CE}$ and only 350 million people in the year $1400 \mathrm{CE}$. After the year 
1500 the population size started to increase steadily and reached today, according to the United Nations Population Division, the number of 7550 million people [26].

The reason for the slow growth rate that occurred after the year $200 \mathrm{CE}$ has seldom been discussed in the literature [27]. We propose here that the slow population growth was a consequence of the increase in population density, which in turn facilitated the spreading of contagious diseases; in many cases the epidemics were a consequence of the use of contaminated water [28]. Only when humanity understood the importance of sanitation and personal hygiene the mortality rate decreased and the number of people started to increase again.

With the advent of agriculture, many factors caused an increase in the transmission of infectious diseases: (1) the substantial increase in population density, which facilitates contagion; (2) the sharing of the same surroundings for sleeping, often used together with domestic animals; (3) the ignorance of the mechanisms of contagion and the non-observance of hygienic rules; (4) the accumulation of microorganisms in food stored for long time before eating; (5) the accumulation of manure, of animal or human origin and the lack of precautions in its use (microorganisms can make up to $60 \%$ of the dry mass of the faeces); (6) the use of contaminated water; (7) the increase in number of the insects acting as vectors of an infective agent; (8) travel to other regions, due for example to the trade of products, thus contributing to the spreading of diseases. The increase in morbidity rate connected with some of the agriculture-associated practices was already noted long time ago: even Herodotus writes "wheat is cultivated with manure and therefore the life of those who eat it is short" [29]. In conclusion, we stress the fact that the increased frequency of contagious diseases [28] was due to the lifestyle of farmers and to the increase in population density. An important factor in the spreading of contagious diseases was the high amounts of water needed for crops cultivation: this may be used for irrigation but it is dangerous if used for drinking.

Sometimes an infectious disease starts occurring and spreading in an animal species and then the microorganism causing it adapts to human beings (for example this was the case of tuberculosis, that originally appeared in bovines). The promiscuity of animals and humans facilitates a change in target species and the possibility of infecting humans as well: in fact, when an infection is successful, the pathogenic microorganism will multiply enormously (even many billion times), thus increasing the possibility of the chance appearance of few microorganisms that are able to infect also humans (and therefore multiply in humans and spread the disease among them). Moreover, the danger to become infected by a microorganism originated in animals increases substantially when farmers grow them in crowded places, like in the case of poultry or pigs breeding: an infectious agent spreads among the animals and therefore it increases its chances to propagate to humans. Moreover, poultry and livestock farms may be infected with a virus coming from the environment / for example an influenza virus from wild birds) and develop new strains that are able to infect humans and spread through respiratory droplets $[30,31]$.

In conclusion, agriculture permitted an increase in the population size of the planet; but high population density, the proximity with domestic animals, the lack of personal hygiene and the use of contaminated water caused the appearance of many diseases that limited population growth. We wish to stress that population density is essential for human contagion but in some cases contaminated water is a deadly instrument for the spreading of the disease. We have the historical documentation of many epidemics that caused the death of millions of people [32]. The severity of epidemics is confirmed by the description of genetic diseases that confer some resistance to a specific infectious disease: in fact, the frequency of genotypes conferring resistance to a specific disease increases among the survivors to an epidemic [33].

Typhoid fever, caused by Salmonella typhi, is spread by contamination of food or drinking water with the faeces of an infected person or by the contact with flying insects feeding on faeces [34]. According to Thucydides, a plague, probably typhoid fever, killed in 430 BCE $25 \%$ of the population of Athens, thus ending the golden age of Pericles and the dominance of Athens in the Greek world [35,36]. 
The plague of Justinian, which first emerged during the reign of the Emperor of the Byzantine Empire Justinian, caused Europe's population to drop by around $50 \%$ between the 6th and 8th centuries CE. Its effect is clearly reflected in the data reported by Kremer and quoted above [25]: the number of people indicated in the year $400 \mathrm{CE}$ is 190 million and increased only to 200 million in the year $600 \mathrm{CE}$.

The Black Death pandemic of the 14th century, caused by the bacterium Yersinia pestis, reduced the world population from an estimated 450 million in 1340 to between 350 and 375 million in 1400 (a drop of about $20 \%$ ).

Many deadly smallpox epidemics are described in the literature [37]. They were described in India, Egypt and China as early as 1500 years BCE and several centuries later in Europe (smallpox was eradicated in 1977).

Gastroenteritis (also called diarrheal disease) may be caused by a virus or a bacterium or a parasite; it is usually caused by food or water contaminated by faeces but sometimes it comes directly from contacts with an infected person [38,39]. Gastroenteritis infections cause diarrhoea and have been deadly during history. Still today 2 to 5 billion cases of infectious diarrhoea occur per year, mainly in poor areas, where sanitation is not given enough care. Although their lethality decreased substantially, they may cause almost 1 million deaths per year, mainly in areas of greatest population growth and among young children $[40,41]$.

Cholera, caused by the bacterium Vibrio cholerae, spreads mostly by the use of unsafe water but also by food contaminated with human faeces containing the bacteria [42]. Historical descriptions of a dysentery resembling cholera are found as early as the 5th century BCE. Humans are the only animals affected and still today 3 to 5 million people worldwide become sick with cholera, which causes 30,000 to 130,000 deaths per year. During cholera infection the aquaporin water transporter is down regulated, probably in an attempt of the host to counteract the abundant secretion of water with diarrhoea [43]. Mutations causing cystic fibrosis are rather frequent in humans, possibly because, when in the heterozygote state, they cause resistance to cholera [44]. In fact, the cystic fibrosis transmembrane conductance regulator has been suggested to activate a specific aquaporin in airway epithelial cells [45].

Malaria is caused by the protozoon Plasmodium, transmitted by a mosquito [46]. Plasmodium probably existed already long time ago (even 100,000 years) but its population size increased 10,000 years ago with the advent of agriculture and the development of human settlements. In some cases, farmers realized that it was better to live on top of the hills, where mosquitos are rare but they had to go downhill to work in the farms where marshes favoured the growth of infectious mosquitos and in this way the danger to contract malaria increased. Mutations in different human genes have been selected because, under certain conditions, cause resistance to malaria [47].

In the case of other diseases, the contagion takes place through direct contact with sick people (and of course the chances of this event increase when humans live in crowded places). Smallpox is caused by a virus, usually transmitted through droplets coming from the oral, nasal or pharyngeal mucosa of an infected person. Tuberculosis, caused by the bacterium Mycobacterium tuberculosis, is usually transmitted in droplets coming from an infected person.

Several other diseases are directly or indirectly caused by unsafe water: for example, amoebiasis, cryptosporidiosis, dengue, hepatitis A, giardiasis, legionellosis and so on [48].

In conclusion, many people in the past died because of infection by different microorganisms; one factor for diseases spreading was the high density of people; another was the use of contaminated material, in most cases water. For a long time, people believed that the use of water to clean the body was dangerous and as a consequence they did not wash themselves: they used perfumes to cover the unpleasant odours and removed fleas manually. A slow process led to the understanding that something could be done to prevent the spreading of diseases. One way to reduce contagion was to leave crowded towns and move to isolated places: in the Decameron (written in the year 1353) Boccaccio describes a group of young people that decide to leave Florence, where in the year 1348 a plague was killing many people and move to the country to avoid the danger of contagion. Later on, 
it was realized that the use of out of town thermal baths was not only useful for the convalescence of sick people but also to protect the health of the accompanying persons. Population growth started again and it was due mainly to a decline in mortality from infectious diseases [49], due to a better understanding of the danger to use contaminated water and of the importance of personal hygiene and of sanitary structures. Thus, water for sanitation has become important but it is required in amounts much higher than the 2 litres per day per person needed for drinking.

The frequency of waterborne diseases is higher in countries where water distribution and wastewater treatment are not appropriate; inadequate sanitation is considered by the World Health Organization responsible for $4 \%$ of all deaths worldwide. Of course, an epidemic originating in a specific country increases the probability to spread the disease to well organized countries and for this reason it is in the interest of all countries to prevent the occurrence of waterborne diseases; WHO provides an appropriate forum where to discuss this issue.

Prevention of the spreading of waterborne diseases requires an appropriate management of the water used by humans. At the same time the reduction in mortality rate consequent to an efficient prevention causes an increase in population size, thus leading to new necessities in water management.

\section{Management of Water Resources}

The primary source of freshwater for the use of human beings comes from the water that runs off after rain and feeds rivers, lakes and aquifers. However, freshwater is unevenly distributed on the planet: about three-quarters of the annual precipitations occur in specific areas and about $80 \%$ of the available freshwater is located in few basins, like in the Great Lakes of North America, in Africa and in the Baikal lake of Siberia; or in the five major fluvial systems: Amazon, Ganges with Brahmaputra, Congo, Yangtze and Orinoco. Large parts of the globe do not have enough water for human use and in many cases transport of water from nearby zones is required. In a growing number of cases freshwater is produced by desalination (see below).

The development of agricultural practices allowed the feeding of more people per hectare, thus inducing an increase in population size. Human beings soon realized that it was useful to move water to zones were land fertility could be increased through irrigation. Appropriate canals were constructed already a long time ago: remains of them, dating perhaps from the 6th millennium BCE, can be seen in Iran; others, built at least three millennia BCE, are found in India or China; and others, built one or two millennia BCE, have been found in Africa, departing from the Niger River. With the discovery of the New World, the Spanish conquistadores were astonished at the sight of a network of canals covering, on the Andes of Peru, an area of about $700 \mathrm{~km}^{2}$; these canals were dug into the rock with rudimentary stone tools and without the help of animals.

Many canals were built in modern times and today the irrigated areas of the planet are very large: the 2008 estimate was about 3 million $\mathrm{km}^{2}$, almost $70 \%$ of which are located in Asia, $15 \%$ in America and the rest distributed between Europe, Africa and Oceania. The following are few examples of modern structures built for the transfer of water. The aqueduct of Arizona is an open-air canal, $540 \mathrm{~km}$ long, constructed to provide irrigation of 400,000 hectares of land in Arizona. The aqueduct of California is a complex system of canals, tunnels and pipelines having a total length of about $1100 \mathrm{~km}$. In Libya, the Great Man-Made River was built to transport water extracted from more than 1300 wells located in the South of the country in order to distribute it to the cities of Tripoli, Sirte and Benghazi. The transport of water required the assembly of large pipelines, for a total length of $3000 \mathrm{~km}$. Unfortunately, the pipelines were damaged in 2011 during a war conflict and for this reason the Libyan cities are today facing a water shortage. This is a good example of the tight relationship between water needs and security [50]. Extensive use of water for irrigation has caused many cases of aquifers exhaustions, river depletion (for example the Yellow River, the Indus, the Colorado, the Nile) and a serious decrease in the volume of some lakes, as in the case of the Aral Sea [51]. Sometimes water sharing becomes a problem because of climate change or because two or more States do not agree in 
the sharing of the water of a lake or of a river or of an aquifer. A recent publication dealing with these problems is the World Water Development Report 2019 [52].

The management and supply of water for irrigation is facilitated by the use of dams, mostly built in modern times. In 1997 the World Commission on Dams estimated that 800,000 dams exist in the world and contribute to $12-16 \%$ of the global agricultural production.

As stressed above, agriculture also changed the nomadic habits of people, who became sedentary and started new activities, like the production of artisan tools and their trading: this led to a social division of labour and a social stratification, thus generating the appearance of towns. Today the management of water resources for the inhabitants of a city is a complex problem. It implies to provide enough water for drinking and for personal hygiene; to manage the disposal of wastewater and to use structures that avoid the spreading of waterborne diseases; at the same time, it is important to provide enough water for irrigation. In this respect, it is interesting to reflect on what happened during the development and expansion of ancient Rome. This city was founded in the 8th century BCE (the year 753 , according to the legend) when it was inhabited by very few people, perhaps a few thousand; at the time of maximum expansion it approached (or perhaps exceeded) one million people. This remarkable increase was also permitted by the efficient management of the freshwater used and by an accurate wastewater disposal. The city of Rome grew from small settlements, mainly located on the hills called Palatinus, Capitolinus and Aventinus, which were close to a ford on the river Tiber. The inhabitants used the river for procuring water, for fishing, for navigation and to exchange goods with the Etruscans that lived on the other bank of the river. They also used water coming from few springs that were located on the top of the hills and disposed of their waste material downhill. The Romans were open to immigration and therefore the number of inhabitants increased rapidly. As a consequence, they needed: (1) more space; (2) more water; and (3) a waste disposal structure. They began to settle in the space located between the hills and increased the provision of water by taking it from springs located far from Rome and transported through aqueducts built for this purpose. They soon realized that drinking water should not be mixed with wastewater and, to cope with the problems related to the needs of waste disposal, they started building a sewer. This was originally built around the year 600 $\mathrm{BCE}$ as an open-air canal that drained the sewage to the river Tiber; later on, the Romans covered the canal and turned it into a sewer system for the city, called the "Greatest Sewer" (Cloaca Maxima). In the city of Rome, therefore, we observe the first example of an accurate separation between clean water and wastewater (today many countries have built sewer networks and wastewater treatment facilities that have reduced the incidence of waterborne diseases). At the time of maximum expansion, the city of Rome utilized 11 aqueducts that carried $700,000 \mathrm{~m}^{3}$ of water per day. At the same time, about 600 aqueducts were built throughout the Roman Empire (in Italy, Spain, Germany, France and North Africa) and contributed to the foundation or expansion, of many cities. The main reason to build the aqueducts out of Rome was to increase the efficiency of irrigation and thus to produce food to be imported (and cope with the problem of lack of water for irrigation). In fact, cities need land to grow vegetables and water to irrigate it. But cities have very little space for agriculture and therefore they need to import food. When they do it, they indirectly import the water that has been used to produce it, namely they import water-intensive commodities. The "water footprint" concept has been introduced by Hoekstra and collaborators. It refers to the total volume of freshwater used to produce a specific good, under standard conditions [53].

As discussed above, a long time ago people changed their nomadic habits, became sedentary and established themselves near the farms where they worked. Recently however, almost a century ago, a drastic social change took place: with the advent of the industrial revolution and the increased productivity in agriculture (the so-called green revolution), job opportunities in the country-side decreased and people were attracted by better salaries in the cities or by a higher standard of living and centralized services. The social, economic and environmental problems associated with a predominantly urbanized population are considerably different from those of the rural population of the past. Moreover, the population density is higher and therefore the spreading of contagious 
diseases and of antibiotic resistant pathogens becomes more efficient; therefore, the quantity of water necessary for personal hygiene and sanitation becomes higher [54]. At the same time antibiotic resistant infections are becoming more frequent and their danger is discussed within WHO among the States member of this organization [55].

Large metropolitan areas encounter special problems that are not present in small or medium size cities. A megacity is usually defined as a metropolitan area with a total population in excess of ten million people. The new megacities experienced a recent and rapid urbanization, which sometimes modifies the territory and alters the pre-existing water fluxes, thus creating the necessity to adapt the infrastructures for distribution. Moreover, the administrative boundaries of a megacity may not coincide with those previously existing in the urbanized area and therefore the upgrading of the networks for water delivery and the infrastructures for sewage disposal is more difficult to manage. Finally, in megacities the percentage of impervious soil is high as compared to that of villages and therefore the sewerage system should be able to combine the management of the usual type of urban waste with the abundant rain water that occasionally comes from the streets when it rains. In conclusion, in large cities water is distributed through complex and expensive structures; moreover, it is important to establish an accurate system of sanitation performed under the surveillance of a central authority.

Water supply policies and regulations are under the responsibility of the highest Authority of the country. In the ancient Rome the top officer, named "curator aquarum" reported directly to the Emperor. Today the Member States of the European Union conform their decisions to the European Directive number 60/2000. Water and sanitation policy in the USA is under the responsibility of the Environmental Protection Agency, which reports directly to the President. In most other countries the responsibility is entrusted directly to different ministries, as the Ministry of Environment or the Ministry of Health, of Public Works and so forth. In general, the political authorities publish each year a report on the diseases presumably caused by contaminated water and share this information with the World Health Organization. The publication of these data contributes to raise the awareness of the public opinion and thus it may induce the governments to increase the prevention of diseases caused by contaminated water.

Water supply for personal use should in principle reach all private houses, $24 \mathrm{~h}$ per day, at constant pressure. It should be clean, non-toxic and free from pathogenic microorganisms. For this reason, before distribution, the level of a detailed list of substances is analysed, as well as the presence of specific microorganisms; the analyses are repeated at predetermined intervals of time and numerous samples are taken at different points of the distribution chain. The results of the analyses are communicated to the authority entrusted for surveillance and are publicized. When a specific parameter increases over a certain value, predetermined precautions are enforced. It should be pointed out that taste cannot be determined through chemical and microbiological analyses and therefore water distributed by water companies, although safe, sometimes is not pleasant to drink. Furthermore, the parameters analysed are not necessarily complete, since new advances in technology may introduce into the environment new substances that may be toxic [56]. For this reason, the existing rules are sometimes revised and the analysis of one or more parameters is added.

Water has become very important from an economic point of view but the economic value of something that is essential for human survival and for human dignity is difficult to define. Moreover, lack of water and of sanitation structures favours the appearance of contagious diseases that later on spread to all sectors of the population: it is therefore in the interest of society to make available to everybody enough water for sanitation. One principle that is widely accepted is that the price should be affordable by all citizens, including the very poor. Moreover, when there is a shortage, water should be distributed with impartiality.

Wastewater management for appropriate sanitation is more important today as compared to the past: in fact, our hunter-gatherer ancestors produced very little pollution per person as compared to what happens today and water contamination is today more frequent because of the presence of 
domestic animals [57]. Wastewater sanitation is today insufficient in many parts of the world and proper management of sewer material should become a priority. This is important to preserve the quality of freshwater necessary for humanity: in fact, today, as the percentage of the total available freshwater required for human purposes is increasing (see below), it is becoming more important to preserve the water that is not used. The effluent of the wastewater treatment plants sometimes is reused for different purposes, as recovery of nutrients or irrigation or even drinking. Wastewater treatment is usually adapted to the type of material received by the depurator plant. After separation of solid material, a prolonged aeration is used to allow microbial digestion of organic substances and of nitrates, followed by disinfection to kill pathogenic bacteria. Membrane filtration may be used to remove some impurities. Thus, the wastewater treatment plants contain complex apparatus of different types. Wastewater treatment is more complex in a city as compared to that required for a small village [58]. Sewage treatment plants receive all types of hazardous waste from households, hospitals and industries. Combined sewers require much larger and more expensive treatment facilities as compared to plants serving small, well defined areas and therefore it is sometimes more practical and less expensive to use different waste disposal plants that are specialized for the substances produced in different portions of the city. In fact, there are potentially thousands of components of sludge that remain untested or undetected and are disposed of from modern society and that have been proven to be hazardous to both human and ecological health. Residents living in certain zones of the city sometimes show an increased risk for certain respiratory, gastrointestinal and other diseases [59]. Although correlation does not imply causation, these observations may lead to conclude that precaution is necessary.

Water desalination is widely used in different parts of the world [60]. According to the International Desalination Association, in 2015 there were more than 18,000 plants worldwide, mainly located in arid areas, providing water for 300 million people. Most of these plants use membranes to separate water (usually seawater) from the dissolved salts; energy is needed to apply pressure on one side of the membrane. Less energy would be required if the permeability of membranes to water is selectively enhanced and some private companies are beginning to try to use analogues of the aquaporin proteins to increase the efficiency of the process [61,62].

In conclusion, the management of water availability has been a major factor in the development of humanity. Therefore, it is crucial to be prepared to make water available for a growing population and at the same time take care of appropriate sanitation.

\section{Future Needs}

We describe an intricate relationship between water availability, food production, increase in the world population, contagious diseases.

In principle a human being needs only $2 \mathrm{~L}$ of water per day for drinking. Hunter-gatherers needed very little extra water but today the situation is drastically changed and human beings need enormous quantities of water: in the year 2000, according to the Environmental Outlook published by OECD [63], $2384 \mathrm{~km}^{3}$ of water were consumed for irrigation; $504 \mathrm{~km}^{3}$ were consumed for industrial purposes and $348 \mathrm{~km}^{3}$ for domestic purposes. Note that water for irrigation is needed in specific places (where farms are present) and at specific times (when plant growth and ripening are occurring) [51], thus making this requirement more stringent. Moreover, as described in this Review, the use of domestic water is important to prevent the spreading of contagious diseases. It is worth noting that the human population increased because of agriculture production and developed where water was abundant; but today much water per person is needed to support people in areas where water is scarce. Globally, much more water will be needed in the future and the above quoted OECD document predicts that the total amount of water needed on the globe, $3236 \mathrm{~km}^{3}$ in the year 2000 , will increase to $5420 \mathrm{~km}^{3}$ in the year 2050 .

Water availability is not sufficient today [64]: in the poorest areas of the planet more than 2 billion people use on average 10 litres of water per day per person, thus generating migrations and wars. 
Moreover, it would be a common interest of poor and rich countries to provide enough water for sanitation to avoid the occurrence and spreading of infectious diseases [65].

The population of the planet increased in the last centuries mainly because of a decrease in mortality [49] and therefore it is unlikely that the present trend of population increase will change in the immediate future. Thus, the freshwater requirement will increase dramatically, not only to give water in an equitable way to everybody on the planet but also because demographic studies (see Table 1 in Ref. [26]) indicate that the total amount of people on the globe will increase to about 9800 million by the year 2050: therefore, we should be prepared to give enough water to an increased population $[66,67]$. Moreover, the density of people in certain areas will increase, thus increasing the danger of disease contagion; as a consequence, the use of water for sanitation will become more important and more attention should be given to the prevention of some diseases (for example through vaccination or better ecological management).

The water volume of rivers is about $2100 \mathrm{~km}^{3}$ [3]; keeping in mind that part of this water is used to feed lakes and aquifers, we should begin to think in terms of total amount of rainfall water per year and compare the human needs to the figures assigned to the different components of the water repositories.

The provision of water will have a great social, financial and political relevance; all social sectors will have to be involved and many habits will have to change.

Acknowledgments: The author warmly thanks Anna Maria Aliperti for manuscript editing.

Conflicts of Interest: The author declares no conflict of interest.

\section{References}

1. Gleick, P.H. Water in Crisis: A Guide to the World's Fresh Water Resources; Oxford University Press: New York, NY, USA, 1993; ISBN 9780195076288.

2. Boberg, J. Withdrawing Liquid Assets: How Demographic Changes and Water Management Policies Affect Freshwater Resources; Rand Labor and Population: Santa Monica, CA, USA, 2005; ISBN 0-8330-3807-9.

3. Shiklomanov, I.A. Appraisal and Assessment of World Water Resources. Water Int. 2009, 25, 11-32. [CrossRef]

4. Eckstein, G. The International Law of Transboundary Groundwater Resources; Taylor Francis Ltd.: Abingdon, UK, 2017; ISBN 9781138842991.

5. Bengtsson, L. The Earth's Hydrological Cycle; Springer: Berlin, Germany, 2014; ISBN 978-94-017-8789-5.

6. Agre, P.; Brown, D.; Nielsen, S. Aquaporin water channels: Unanswered questions and unresolved controversies. Curr. Opin. Cell Biol. 1995, 7, 472-483. [CrossRef]

7. Kapilan, R.; Vaziri, M.; Zwiazek, J.J. Regulation of aquaporins in plants under stress. Biol. Res. 2018, 51, 4. [CrossRef] [PubMed]

8. Curry, R.; Dickson, B.; Yashayaev, I. A change in the freshwater balance of the Atlantic Ocean over the past four decades. Nature 2003, 426, 826-829. [CrossRef] [PubMed]

9. Takei, Y. From Aquatic to Terrestrial Life: Evolution of the Mechanisms for Water Acquisition. Zool. Sci. 2015, 32, 1-7. [CrossRef] [PubMed]

10. Lema, S.C.; Carvalho, P.G.; Egelston, J.N.; Kelly, J.T.; McCormick, S.D. Dynamics of gene expression responses for ion transport proteins and aquaporins in the gill of a euryhaline pupfish during freshwater and high salinity acclimation. Physiol. Biochem. Zool. 2018, 91, 1148-1171. [CrossRef] [PubMed]

11. Jha, U.C.; Bohra, A.; Jha, R.; Parida, S.K. Salinity stress response and 'omics' approaches for improving salinity stress tolerance in major grain legumes. Plant Cell Rep. 2019. [CrossRef]

12. Herodotus. Histories, Book 1: Clio; SMK Books: Plano, TX, USA, 2014; p. 200, ISBN-10 1617207691.

13. Leonardi, M.; Barbujani, G.; Manica, A. An earlier revolution: Genetic and genomic analyses reveal pre-existing cultural differences leading to Neolithization. Sci. Rep. 2018, 9, 682. [CrossRef]

14. Diamond, J. Guns, Germs and Steel: The Fates of Human Societies; W.W. Norton: New York, NY, USA, 1997; ISBN 0-393-31755-2. 
15. Hassan, F. Water History for Our Times. IHP Essays on Water History; UNESCO Publishing: Paris, France, 2011; Volume 2, Available online: http:/ / unesdoc.unesco.org/images/0021/002108/210879e.pdf (accessed on 19 February 2019).

16. Bellwood, P. First Farmers: The Origins of Agricultural Societies; Wiley-Blackwell: Hoboken, NJ, USA, 2004; ISBN 978-0-631-20566-1.

17. Smil, V. Energy and Civilization: A History; MIT Press: Cambridge, MA, USA, 2017; ISBN 9780262035774.

18. Ercumen, A.; Pickering, A.J.; Kwong, L.H.; Arnold, B.F.; Parvez, S.M.; Alam, M.; Sen, D.; Islam, S.; Kullmann, C.; Chase, C.; et al. Animal faeces contribute to domestic fecal contamination: Evidence from E. coli measured in water, hands, food, flies and soil in Bangladesh. Environ. Sci. Technol. 2017, 51, 8725-8734. [CrossRef]

19. Schoen, M.E.; Soller, J.A.; Ashbolt, N.J. Evaluating the importance of faecal sources in human-impacted waters. Water Res. 2011, 45, 2670-2680. [CrossRef]

20. Headey, D.; Nguyen, P.; Kim, S.; Rawat, R.; Menon, P. Is Exposure to Animal Feces Harmful to Child Nutrition and Health Outcomes? A Multicountry Observational Analysis. Am. J. Trop. Med. Hyg. 2017, 96, 961-999. [CrossRef] [PubMed]

21. Schraiber, J.G.; Akey, J.M. Methods and models for unravelling human evolutionary history. Nat. Rev. Genet. 2015, 16, 727-740. [CrossRef] [PubMed]

22. Petraglia, M.; Clarkson, C.; Boivin, N.; Haslam, M.; Korisettar, R.; Chaubey, G.; Ditchfield, P.; Fuller, D.; James, H.; Jones, S.; et al. Population increase and environmental deterioration correspond with microlithic innovations in South Asia ca. 35,000 years ago. Proc. Natl. Acad. Sci. USA 2009, 106, 12261-12266. [CrossRef] [PubMed]

23. McEvedy, C.; Jones, R. Atlas of World Population History; Penguin: London, UK, 1978; ISBN1 0713910313, ISBN2 9780713910315.

24. Biraben, J.-N. Essai sur l'évolution du nombre des hommes. Population 1979, 34, 13-25. [CrossRef]

25. Kremer, M. Population Growth and Technological Change: One Million, B.C. to 1990. Q. J. Econ. 1993, 108, 681-716. [CrossRef]

26. World Population Prospects. Available online: https://esa.un.org/unpd/wpp/Publications/Files/ WPP2017_KeyFindings.pdf (accessed on 19 February 2019).

27. Armelagos, G.J.; Goodman, A.H.; Jacobs, K.H. The origins of agriculture: Population growth during a period of declining health. Popul. Environ. 1991, 13, 9-22. [CrossRef]

28. Percival, S.L.; Yates, M.V.; Williams, D.D.; Chalmers, R.; Gray, N. Microbiology of Waterborne Disease; Elsevier: Amsterdam, The Netherlands, 2014; ISBN 978-0-12-415846-7.

29. Herodotus. Histories, Book 8 (Thalia); Cambridge University Press: Cambridge, UK, 2008; ISBN 9780521575713.

30. Yassine, H.M.; Lee, C.W.; Saif, Y.M. Interspecies transmission of influenza a viruses between Swine and poultry. Curr. Top. Microbiol. Immunol. 2013, 370, 227-240. [CrossRef]

31. Donatelli, I.; Castrucci, M.R.; De Marco, M.A.; Delogu, M.; Webster, R.G. Human-Animal Interface: The Case for Influenza Interspecies Transmission. Adv. Exp. Med. Biol. 2017, 972, 17-33. [CrossRef]

32. Kohn, G.C. Encyclopedia of Plague and Pestilence: From Ancient Times to the Present; Checkmark Books: Princeton, NJ, USA, 2002; p. 454, ISBN-10 9780816048939.

33. Withrock, I.C.; Anderson, S.J.; Jefferson, M.A.; McCormack, G.R.; Mlynarczyk, G.S.A.; Nakama, A.; Lange, J.K.; Berg, C.A.; Acharya, S.; Stock, M.L.; et al. Genetic diseases conferring resistance to infectious diseases. Genes Dis. 2016, 2, 247-254. [CrossRef]

34. Crump, J.A.; Mintz, E.D. Global trends in typhoid and paratyphoid fever. Clin. Infect. Dis. 2010, 50, $241-246$. [CrossRef]

35. Thucydides. History of the Peloponnesian War; Penguin Books: London, UK, 2004; Chapter VII; ISBN 9780142004371.

36. Littman, R.J. The Plague of Athens: Epidemiology and Paleopathology. Mt. Sinai J. Med. 2009, 76, 456-467. [CrossRef] [PubMed]

37. Hopkins, D.R. The Greatest Killer: Smallpox in History; University of Chicago Press: Chicago, IL, USA, 2002; ISBN 978-0-226-35168-1.

38. Lim, M.L.; Wallace, M.R. Infectious diarrhea in history. Infect. Dis. Clin. N. Am. 2004, 18, 261-274. [CrossRef] [PubMed] 
39. Prüss-Ustün, A.; Bartram, J.; Clasen, T.; Colford, J.M., Jr.; Cumming, O.; Curtis, V.; Bonjour, S.; Dangour, A.D.; De France, J.; Fewtrell, L.; et al. Burden of disease from inadequate water, sanitation and hygiene in lowand middle-income settings: A retrospective analysis of data from 145 countries. Trop. Med. Int. Health 2014, 19, 894-905. [CrossRef] [PubMed]

40. Ercumen, A.; Gruber, J.S.; Colford, J.M., Jr. Water distribution system deficiencies and gastrointestinal illness: A systematic review and meta-analysis. Environ. Health Perspect. 2014, 122, 651-660. [CrossRef] [PubMed]

41. GBD Diarrhoeal Diseases collaborators. Estimates of global, regional and national morbidity, mortality and aetiologies of diarrhoeal diseases: A systematic analysis for the Global Burden of Disease Study 2015. Lancet Infect. Dis. 2017, 17, 909-948. [CrossRef]

42. Nair, G.B.; Takeda, Y. Cholera Outbreaks; Springer: Berlin/Heidelberg, Germany, 2014; ISBN 978-3-642-55404-9.

43. Flach, C.F.; Qadri, F.; Bhuiyan, T.R.; Alam, N.H.; Jennische, E.; Holmgren, J.; Lönnroth, I. Differential expression of intestinal membrane transporters in cholera patients. FEBS Lett. 2007, 581, 3183-3188. [CrossRef]

44. Gabriel, S.E.; Brigman, K.N.; Koller, B.H.; Boucher, R.C.; Stutts, M.J. Cystic fibrosis heterozygote resistance to cholera toxin in the cystic fibrosis mouse model. Science 1994, 266, 107-109. [CrossRef] [PubMed]

45. Schreiber, R.; Nitschke, R.; Greger, R.; Kunzelmann, K. The cystic fibrosis transmembrane conductance regulator activates aquaporin 3 in airway epithelial cells. J. Biol. Chem. 1999, 274, 11811-11816. [CrossRef] [PubMed]

46. Carter, R.; Mendis, K.N. Evolutionary and Historical Aspects of the Burden of Malaria. Clin. Microbiol. Rev. 2002, 15, 564-594. [CrossRef]

47. Kwiatkowski, D.P. How Malaria has affected the human genome and what human genetics can teach us about malaria. Am. J. Hum. Genet. 2005, 77, 171-192. [CrossRef]

48. Water Related Diseases Surveillance. Available online: http://www.unece.org/fileadmin/DAM/env/ water/cadialogue/docs/Almaty_Oct2011/Presentations_Eng/11.Shinee_WRD_Eng.pdf (accessed on 19 February 2019).

49. McKeown, T. The Modern Rise of Population; Academic Press: Cambridge, MA, USA, 1976; ISBN-10 0124855504.

50. Feitelson, E.; Tubi, A. A main driver or an intermediate variable? Climate change, water and security in the Middle East. Glob. Environ. Chang. 2017, 44, 39-48. [CrossRef]

51. Falkenmark, M.; Lannerstad, M. Consumptive water use to feed humanity-Curing a blind spot. Hydrol. Earth Syst. Sci. 2005, 9, 15-28. [CrossRef]

52. World Water Development Report 2019. Available online: https://en.unesco.org/events/world-waterdevelopment-report-2019-official-launch (accessed on 19 February 2019).

53. Hoekstra, A.Y.; Mekonnen, M.M. The Water footprint of Humanity. Proc. Natl. Acad. Sci. USA 2012, 109, 3232-3237. [CrossRef] [PubMed]

54. Wuijts, S.; van den Berg, H.H.; Miller, J.; Abebe, L.; Sobsey, M.; Andremont, A.; Medlicott, K.O.; van Passel, M.W.; de Roda Husman, A.M. Towards a research agenda for water, sanitation and antimicrobial resistance. J. Water Health 2017, 15, 175-184. [CrossRef] [PubMed]

55. World Health Organization. Antimicrobial Resistance: An Emerging Water, Sanitation and Hygiene Issue. World Health Organization Briefing Note. WHO/FWC/WSH/14.7. Available online: https:/ /www.who. int/water_sanitation_health/publications/antimicrobial-resistance/en/ (accessed on 19 February 2019).

56. Golea, D.M.; Upton, A.; Jarvis, P.; Moore, G.; Sutherland, S.; Parsons, S.A.; Judd, S.J. THM and HAA formation from NOM in raw and treated surface waters. Water Res. 2017, 112, 226-235. [CrossRef] [PubMed]

57. Wastewater, The Untapped Resource; The United Nations World Water Development Report 2017; UNESCO Digital Library: Paris, France, 2017; ISBN 978-92-3-100201-4.

58. Iaccarino, M. Como obtenir agua de buena calidad en las ciudades en desarrollo. In Laudato si' $y$ grandes ciudades. Propestuas de una Ecologia Integral; Los Libros de la Catarata: Madrid, Spain, 2018; ISBN 978-84-9097-448-3.

59. Rushton, L. Health hazards and waste management. Br. Med. Bull. 2003, 68, 183-197. [CrossRef] [PubMed]

60. Kucera, J. Desalination: Water from Water; Wiley: Hoboken, NJ, USA, 2014; ISBN-13 978-1118208526.

61. Nielsen, C.H. Biomimetic membranes for sensor and separation applications. Anal. Bioanal. Chem. 2009, 395, 697-718. [CrossRef] [PubMed] 
62. To, J.; Torres, J. Can Stabilization and Inhibition of Aquaporins Contribute to Future Development of Biomimetic Membranes? Membranes 2015, 5, 352-368. [CrossRef] [PubMed]

63. OECD. Environment: The Water Challenge: Sharing a Precious Commodity. March 2012. Available online: http:/ / www.oecd.org/environment/environmentthewaterchallengesharingapreciouscommodity. htm (accessed on 19 February 2019).

64. Rodell, M.; Famiglietti, G.S.; Wiese, D.N.; Reager, J.T.; Beaudoing, H.K.; Landerer, F.W.; Lo, M.-H. Emerging Trends in global freshwater availability. Nature 2018, 557, 651-659. [CrossRef] [PubMed]

65. United Nations Development Programme. Human Development Report, Beyond Scarcity: Power, Poverty and the Global Water Crisis; UNDP: New York, NY, USA, 2006; ISBN 0-230-50058-7.

66. Vorosmarty, C.J.; Green, P.; Salisbury, J.; Lammers, R.B. Global water resources: Vulnerability from climate change and population growth. Science 2000, 289, 284-288. [CrossRef]

67. Schlosser, C.A.; Strzepek, K.; Gao, X.; Fant, C.; Blanc, E.; Paltsev, S.; Jacoby, R.; Reilly, J.; Gueneau, A. The future of global water stress: An integrated assessment. Earths Future 2014, 2, 341-361. [CrossRef]

(C) 2019 by the author. Licensee MDPI, Basel, Switzerland. This article is an open access article distributed under the terms and conditions of the Creative Commons Attribution (CC BY) license (http:/ / creativecommons.org/licenses/by/4.0/). 